\title{
The Renin Angiotensin System and the Metabolic Syndrome
}

\author{
Chih-Hong Wang, Feng Li and Nobuyuki Takahashi*
}

\author{
Department of Pathology and Laboratory Medicine, The University of North Carolina at Chapel Hill, 819 \\ Brinkhous-Bullitt Building, Chapel Hill, NC 27599-7525, USA
}

\begin{abstract}
The renin angiotensin system (RAS) is important for fluid and blood pressure regulation. Recent studies suggest that an overactive RAS is involved in the metabolic syndrome. This article discusses recent advances on how genetic alteration of the RAS affects cardiovascular and metabolic phenotypes, with a special emphasis on the potential role of angiotensin-independent effects of renin.
\end{abstract}

Keywords: (Pro) renin receptor, body fat, fecal fat, thermogenesis.

\section{INTRODUCTION}

The metabolic syndrome is a widely accepted concept that identifies the centrally obese patients with increased risk of cardiovascular diseases and diabetes. The syndrome has a rising prevalence worldwide, which related largely to increasing obesity and sedentary lifestyles [1]. In the US approximately $34 \%$ of adults meet the criteria for the metabolic syndrome, and the syndrome is 3 times more prevalent in males and females 40-59 years of age compared to those 2039 years of age [2]. Individuals with the metabolic syndrome have twice the risk of developing cardiovascular disease over the next 5 to 10 years relative to individuals without the syndrome [1]. The syndrome confers 5 -fold risk for type 2 diabetes [1]. The metabolic syndrome is clinically characterized by several inter-related symptoms including obesity, dyslipidemia, high BP, insulin resistance, impaired glucose tolerance or diabetes. Each of these is a risk factor of cardiovascular disease and diabetes, but combinations of them greatly increase the risk of cardiovascular diseases [3]. But there were many definitions of the metabolic syndrome, which led to confusion regarding how to identify patients with the syndrome $[4,5]$, leading to a confusion in clinical practice. The main difference was that The International Diabetes Federation (IDF) had a threshold value for waist circumference as obligatory, whereas American Heart Association/National Heart, Lung, and Blood Institute (AHA/NHLBI) had it one of the factors but not obligatory. Accordingly, IDF and AHA/NHLBI, jointed by the World Heart Federation, International Atherosclerosis Society, and International Association for the Study of Obesity recently developed one unified definition [1] (Table 1): there should be no obligatory component, but waist measurement would continue to be a useful screening tool. Three abnormal findings out of 5 would qualify a person for the metabolic syndrome. A single set of cut points would be used for all components except waist circumference. Yet, because the relation between waist circumference and cardiovascular disease and diabetes risk differs

*Address correspondence to this author at the Department of Pathology and Laboratory Medicine, The University of North Carolina at Chapel Hill, 819 Brinkhous-Bullitt Building, Chapel Hill, NC 27599-7525, USA;

Tel: 919-966-1338; Fax: 919-966-8800; E-mail: ntakaha@med.unc.edu globally, the definition for waist circumference remains unsettled.

High blood pressure is a major factor of the metabolic syndrome, and genetic factors that regulate blood pressure are likely important as a cause of the metabolic syndrome. However, progress has been slow with regard to the identification of genetic factors affecting blood pressure and the metabolic syndrome. This is because hypertension and the metabolic syndrome are probably caused by combinations of a variety of small quantitative changes in the expression of many genes plus a similarly diverse collection of environmental factors.

Current efforts in humans using single nucleotide polymorphisms (SNPs) to identify susceptibility loci containing one or more QTLs (quantitative trait loci) relevant to blood pressure and the metabolic syndrome has the potential to be informative. False-positive and false-negative results are, however, inevitable because the genotype-phenotype associations with QTLs are weaker than those observed with the more direct and severe Mendelian traits, and because nongenomic environmental factors can easily obscure any association. Additionally, even when an association is strong, the possibility remains that the cause of an observed difference in blood pressure and the metabolic syndrome is a linked but unrecognized genetic difference rather than the recognized polymorphic factor.

Using animal models have the potential to overcome some of the genetic and environmental complexities of human studies because we can use homogenous genetic background and environmental condition. Above all generating genetically engineered animals especially using gene targeting technique in mice will allow us to directly study the effects of changing the gene of interest without being obscured by genetic background and environmental factors such as diet. The mouse models generated by gene targeting can establish a causative link between differences in blood pressure or the metabolic syndrome and changes in gene expression in animals that are otherwise unaffected (i.e. wild type) and have all their homeostatic mechanisms intact. The results are often predictive of the effects of genetic polymorphisms in humans. In the reciprocal direction, once naturally occurring 
Table 1. Criteria for Clinical Diagnosis of the Metabolic Syndrome

\begin{tabular}{|c|c|}
\hline & Categorical cutpoints \\
\hline Increased waist circumference* & Population-specific and country-specific definitions \\
\hline Increased triglycerides (drug treatment for elevated TG is alternate indicator $\dagger$ ) & $\geq 150 \mathrm{mg} / \mathrm{dL}(1.7 \mathrm{mmol} / \mathrm{L})$ \\
\hline Reduced HDL cholesterol (drug treatment for reduced HDL cholesterol is alternate indicator $\dagger$ ) & $\begin{array}{l}<40 \mathrm{mg} / \mathrm{dL}(1.0 \mathrm{mmol} / \mathrm{L}) \text { in men } \\
<50 \mathrm{mg} / \mathrm{dL}(1.3 \mathrm{mmol} / \mathrm{L}) \text { in women }\end{array}$ \\
\hline $\begin{array}{l}\text { Increased blood pressure (antihypertensive drug treatment in patient with history of hypertension } \\
\text { is alternate indicator) } \\
\text { Increased fasting glucose } \$ \text { (drug treatment of increased glucose is alternate indicator) }\end{array}$ & $\begin{array}{l}\text { Systolic } \geq 130 \text { and/or diastolic } \geq 85 \mathrm{~mm} \mathrm{Hg} \\
>100 \mathrm{mg} / \mathrm{dL}(5.5 \mathrm{mmol} / \mathrm{L})\end{array}$ \\
\hline
\end{tabular}

*It is recommended that the IDF cutpoints be used for non-Europeans and either the IDF or AHA/NHLBI cutpoints used for people of European origin until more data are available. $\dagger$ Most commonly used drugs for increased triglycerides and reduced HDL cholesterol are fibrates and nicotinic acid. A patient on one of these drugs can be presumed to have high triglycerides and low HDL. Use of high-dose $\omega-3$ fatty acids presumes high triglycerides. $\$$ Most patients with type 2 diabetes will have the metabolic syndrome by the proposed criteria.

candidate allelic variations have been detected in humans, gene targeting can be used to test whether the variations cause differences in blood pressure or the metabolic syndrome in mice. A common feature to all mouse experiments is the ability to change the genetic background of the mutant mice by generating a backcross with a different strain. This type of experiment is valuable because the detection of a difference in the severity of a phenotype in different genetic backgrounds indicates the presence of modifier gene(s) in which expression differs from one strain to another. Identifying such modifier genes can then help uncover genetic differences in humans that have similar effects on the phenotype severity.

The renin angiotensin system (RAS) is one of the most important systems that regulate cardiovascular and fluid homeostasis (Fig. 1). Angiotensins can also act as neurotransmitters, regulating blood pressure (BP), memory, cognition and stress [6-8]. Renin, released from the kidney juxtaglomerular (JG) cells, is a rate-limiting enzyme in angiotensin II (Ang II) production. Renin cleaves the liver- and adiposetissue-derived angiotensinogen (AGT) to form inactive angiotensin I (Ang I) [9]. The angiotensin-converting enzyme (ACE), which is mainly expressed in the endothelium, then removes two $\mathrm{C}$-terminal amino acids and generates active peptide Ang II. Interestingly, the human $A C E$ inser- tion/deletion (ID) polymorphism does not affect BP despite the powerful antihypertensive effects of ACE inhibitors (reviewed in $[10,11])$, although mild increase in ACE causes exacerbation of diabetic nephropathy (see the section on $\mathrm{ACE})$.

The majority of the biological effects of Ang II, including BP elevation, are mediated by the type 1 Ang II receptor (AT1R). An Ang II negative-feedback mechanism inhibits the expression and secretion of renin. Treatments of hypertension often involve the inhibition of RAS with Ang receptor blockers (ARB), ACE inhibitors, or renin inhibitors, all of which disrupt this negative-feedback mechanism and increase renin levels.

In addition to these classical RAS components, several new molecules have been discovered in recent years. A homolog of ACE, ACE2, was discovered and shown to convert Ang II to Ang(1-7) [12]. Santos et al. discovered that the receptor for Ang(1-7) is the Mas proto-oncogene, and that this ACE2-Ang(1-7)-Mas pathway counteracts the effects of Ang II [13]. Furthermore, Nguyen et al. discovered the (pro)renin receptor (PRR) in $2002[14,15]$. This receptor is expressed in many tissues including brain, adipose tissue, endothelial cells, vascular smooth muscle cells, and kidney. PRR binds and activates prorenin. This newly discovered

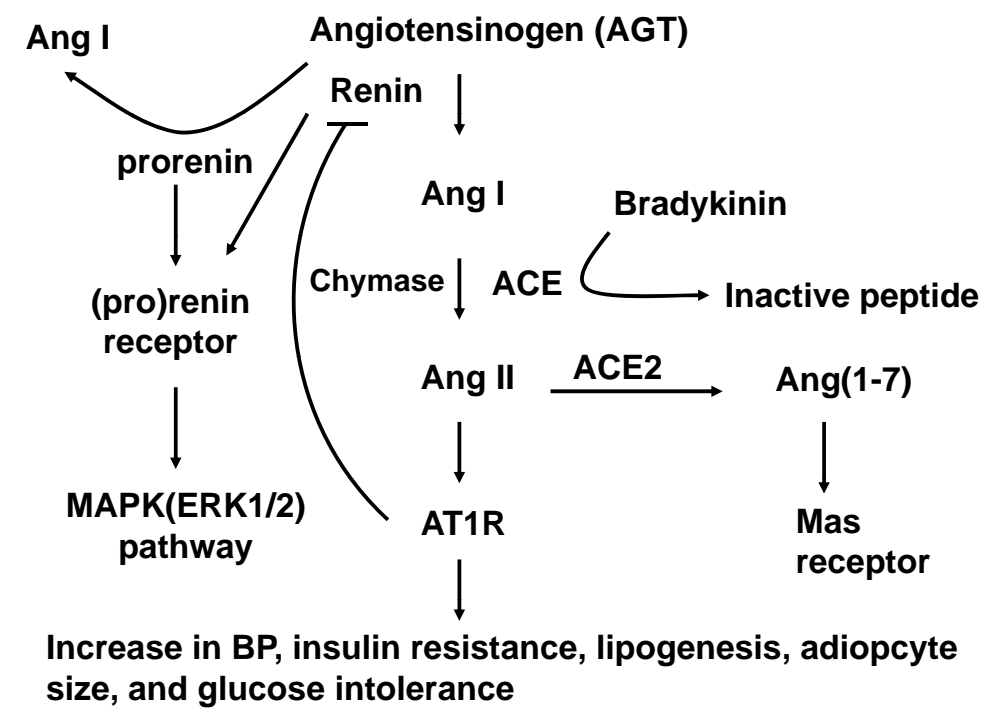

Fig. (1). The Renin-angiotensin system (RAS). Angiotensin II effects are predominately mediated by Ang II type 1 receptor (AT1R). In addition to the classical RAS, ACE2 and (pro)renin receptor are new players of this system. See text in detail. 
RAS component likely impacts local Ang II effects in cardiovascular diseases and the metabolic syndrome.

The RAS recently has been implicated in the metabolic syndrome. Ang II induces adipogenesis (differentiation into adipocytes) $[16,17]$ and lipogenesis (triglyceride storage in adipocytes) in vitro [18]. However, the in vivo role of RAS in the metabolic syndrome has been unclear. The effects of Ang II on adipose tissue are mediated by Ang II type 1 and type 2 receptors.

Accordingly, we will focus on the roles of genetic changes in RAS in mice, rats, and in humans. Although much of the data available are from animal studies, because much of the genes and physiology between mice, rats, and humans are quite similar, it is important to understand information available from animal experiment to better treat human patients with the metabolic syndrome.

\section{Angiotensinogen (AGT)}

AGT is produced in several tissues: liver (the main source of circulating AGT), adipose tissue, kidney, heart, and brain. Using linkage analysis of the variants of the angiotensinogen gene $(A G T)$, Jeunemaitre et al. found that M235T was observed more frequently in hypertensive versus normotensive individuals. In sibling studies, M235T segregates with the hypertensive condition [19]. In addition, individuals with the M235T variant had a higher plasma AGT concentration than individuals with $235 \mathrm{M}$. Subsequently, Inoue et al. demonstrated that the 235 polymorphism is tightly linked with a single polymorphic change in its promoter region ( $\mathrm{G}$ at -6 in $235 \mathrm{M}$, and $\mathrm{A}$ at -6 in $235 \mathrm{~T}$ ). Promoter regions with $A$ at -6 were associated with a greater concentration of plasma AGT [20]. Jain et al. identified an A/G polymorphism at -217 in the $A G T$ gene promoter [21], and showed that, particularly in African-American individuals, an A at -217 is strongly associated with essential hypertension due to increased glucocorticoid binding to the $A G T$ promoter. The association between $A G T$ polymorphism and the metabolic syndrome is not clear.

Mice lacking AGT (Agt-/) have severe hypotension and overexpress renin [22-24]. These mice also have a high rate of neonatal mortality associated with an impaired ability to concentrate urine, and have severe renal abnormalities in- cluding hydronephrosis, and hypertrophy of renal arteries $[23,25]$. Administration of Ang II to the brain can correct hydronephrosis and partially correct the renal dysfunction seen in these mice [25]. In response to mild quantitative changes in AGT by altering the gene copy number of $A g t$, BP levels in 1-, 2-, 3-, and 4-copy mice were progressively increased [22]. This is consistent with what is observed in humans with $A G T$ polymorphisms.

Mice lacking AGT are lean [26]. Although their food intake and fecal fat excretion were similar to those of wildtype mice, the Agt-/- mice have significantly increased energy expenditure due to increased locomotor activity. In addition, the uncoupling proteins (UCP-1, 2, 3), which dissipate heat instead of producing ATP and are found in the mitochondria of brown adipose tissue (BAT), epididymal fat, and skeletal muscle, respectively, did not differ between Agt/- and wild-type mice [26]. The Agt-/- mice exhibited depressed adipose tissue development, which is associated with decreased fatty acid synthase (FAS) activity.

\section{Renin}

Renin is an important enzyme for regulation of BP and cardiovascular homeostasis. Cleavage of AGT to Ang I by renin is a rate-limiting step of Ang II production [27]. Renin is secreted from juxtaglomerular cells, which are modified smooth muscle cells of the afferent arterioles in the kidney. In Spanish populations, individuals with the GG genotype at the rs5707 intron 4 polymorphism of renin have significantly higher BP compared to those with the TT or TG genotype [28]. Individuals with GG genotype of the missense mutation in exon 9 (G1051A) have higher plasma renin activity, and this polymorphism may be involved in the etiology of hypertension [29].

Renin is encoded by a single gene in humans, rats, and some strains of laboratory mice such as C57BL/6, BALB/c, and $\mathrm{C} 3$ (Fig. 2). However, some laboratory mouse strains (eg. 129, DBA/2J) have 2 renin genes (Ren2 and Renld) in tandem on the same chromosome due to naturally happened duplication of the gene. The regulation of expression and tissue specificity of Renld and Ren 2 are different [30], which complicates renin studies. Mice lacking either Renld or Ren2 exhibited no change in BP or any other apparent
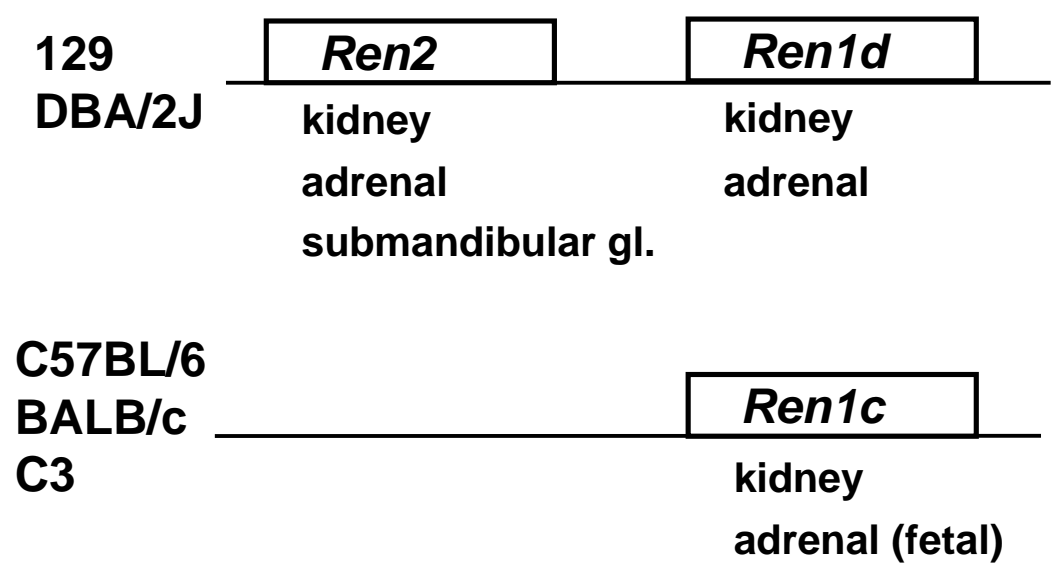

Fig. (2). Mouse renin genes. Renin is encoded by a single gene in humans, rats, and some strains of laboratory mice such as C57BL/6, $\mathrm{BALB} / \mathrm{c}$, and C3. However, some laboratory mouse strains (eg. 129, DBA/2J) have 2 renin genes (Ren2 and Renld) in tandem on the same chromosome through natural duplication. Tissue expression of these renin genes is different. 
phenotype [31, 32], although homozygous mice with Renld replaced with GFP had lower BP [33].

Since C57BL/6 mice, like humans, have only one renin gene, Ren $1 c$, and are susceptible to diet-induced obesity, they are more suitable for research involving changes in renin expression and the metabolic syndrome [30]. Because of the difficulty in generating mice by gene targeting with C57BL/6 embryonic stem cells, Yanai et al. disrupted the Ren1c gene using TT2 ES cells derived from an F1 hybrid between C57BL/6 and CBA [34]. The authors demonstrated that these homozygous mutant mice had undetectable levels of plasma renin activity and plasma Ang I. In addition, the BP of these animals was lower than wild type by $20-30 \mathrm{~mm}$ $\mathrm{Hg}$. The knockouts also had increased urine and drinking water volume and hydronephrosis, as observed in the Agt-/mice. Abnormal granular cell layers in the hippocampus, as observed in the Agt-/- mice [35], were absent in mice lacking renin [34].

We have independently generated mice lacking Renlc using embryonic stem cells from C57BL/6N mice [27]. Our Ren1c-/- mice have low BP and undetectable levels of plasma renin, Ang I, and Ang II [27]. Similar to the Ace-/mice, our Ren $1 c-/-$ mice are anemic, as reflected by their low hematocrit ( $32 \pm 3 \%$ vs. $45 \pm 5 \%$ in wild-type litter mates). Administration of Ang II (200 ng/kg/min) using an osmotic minipump restored BP levels in the Ren lc-/- mice to wildtype levels, but preexisting damage to the kidney medulla by hydronephrosis prevented restoration of the ability to concentrate urine. Heterozygous Ren $1 c+/$ - mice are normal with wild type levels of $\mathrm{BP}$, and their kidney renin mRNA expression and plasma renin concentration are indistinguishable from those of wild type control mice [27].

\section{Metabolic Phenotype of Mice Lacking Renin}

We have recently investigated the role of renin in the metabolic syndrome and demonstrated that the Ren 1 c-/- mice have less than $50 \%$ of wild-type adipose tissue weight, which is consistent with the reduced fat volume of the knockouts analyzed by MRI (Fig. 3). These mice were resistant to diet-induced obesity, although there were no changes in food intake [36]. The Renlc-/- mice had smaller adipocytes in all adipose tissue tested, including white adipose tissue (WAT) and brown adipose tissue (BAT), and reduced hepatic triglyceride. Based on energy balance, the lean phenotype seen in these mice should be due to either increased energy expenditure and/or increased fecal energy loss (Fig. 4). Indeed, the null mice displayed gastrointestinal loss of dietary fat as indicated by a higher steatocrit and a lower daily fat absorption.

Indirect calorimetry showed that, although physical activity was the same in the Renlc-/- and wild-type mice, the Renc1-/- mice displayed increased heat generation and lipid combustion, as indicated by their low respiratory quotient (RQ). These mice require a smaller amount of insulin to maintain the same or lower plasma glucose levels relative to wild types. These results suggest a role for renin in the pathogenesis of diet-induced obesity and insulin resistance. Inhibition of renin may provide a good therapeutic target in the metabolic syndrome.

Other investigators have demonstrated that mice lacking Agt or Ace also have low BP, lean body type, and resistance

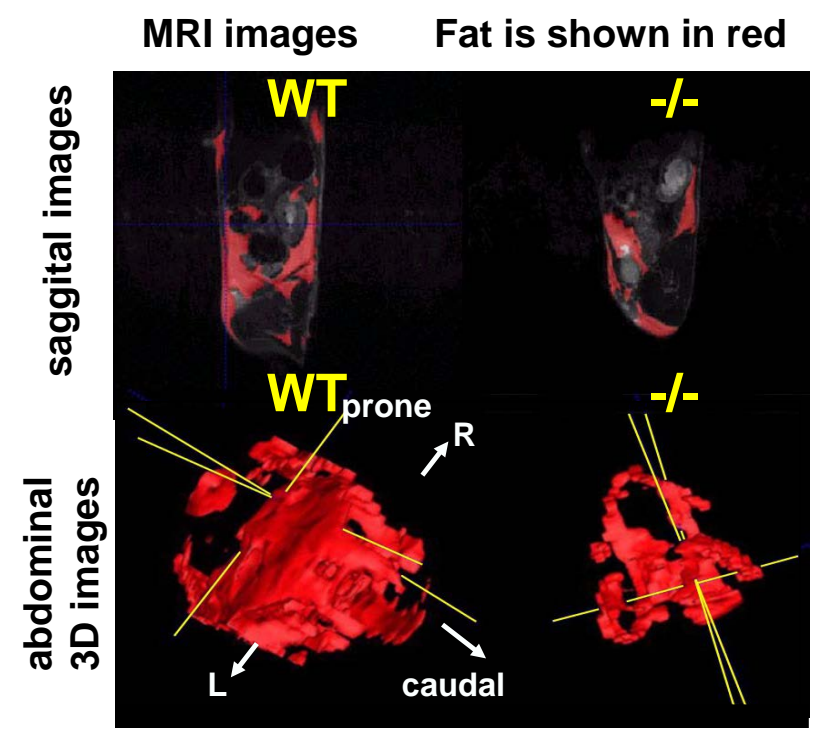

Fig. (3). Reduced adipose tissue in mice lacking renin. The Ren1c-/- mice have less than $50 \%$ of wild-type adipose tissue weight, as analyzed by MRI. Top panels are saggital sections. Bottom panels are $3 \mathrm{D}$ images showing the adipose tissue caudal to the diaphragm constructed from saggital images.

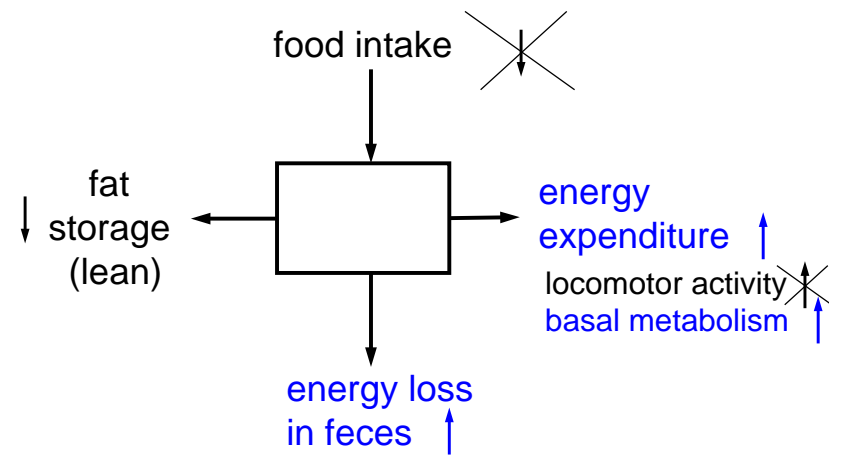

Fig. (4). The energy flow of the Ren1c-/- mice. Mice lacking renin are lean and resistant to diet-induced obesity due to increased energy expenditure and increased fecal energy loss.

to diet-induced obesity. Interestingly, however, these mice are not as lean as mice lacking renin (Table 2).

The Renlc-/- mice also display a unique increase in fecal fat excretion, heat generation, uncoupling protein (UCP1) expression in brown adipose tissue (BAT), and a reduced respiratory quotient (RQ), which were not observed in the Agt-/- and the Ace-/- mice (Table 2). Because BAT is required for most non-shivering thermogenesis in rodents, these data suggest that the Ren $1 c$-/- mice generate more heat by combusting fat in BAT. The Agt-/-, Ace-/- and Renlc-/mice have no detectable levels of Ang II, but different from the Ren $1 \mathrm{c}$-/- mice, both Agt-/- and Ace-/- mice have very high levels of renin due to disruption of a negative feedback mechanism. Accordingly, the lack of Ang-independent effects of renin likely contributes to decreased adiposity by decreasing dietary fat absorption and increasing heat generation. This possibility is currently being investigated.

\section{Human Renin Transgenic Mice}

Consistent with the Ang-independent effects of renin on adiposity, human renin transgenic ( $h R E N T g$ ) mice weigh 
Table 2. Metabolic Phenotypes of Mice Lacking Renin, AGT and ACE

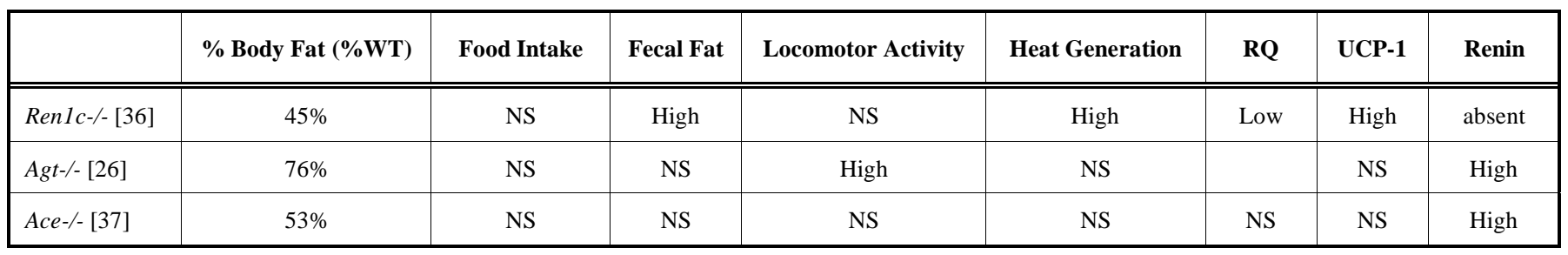

RQ: respiratory quotient, UCP1: uncoupling protein 1 , NS, not significantly different from wild type controls.

twice as much as wild-type mice at 60 weeks of age and display normal BP [38]. BP and plasma Ang II levels in $h R E N$ $T g$ mice are indistinguishable from wild-type mice, while double transgenic mice harboring both $h R E N T g$ and $h A G T$ $T g$, have high BP and Ang II levels [39], suggesting that human renin does not generate Ang I from mouse AGT. Indeed, when incubated with plasma from our Ren1c-/- mice, which contains high levels of mouse AGT, exogenous recombinant human renin $\left(10^{-12 \sim 8} \mathrm{M}\right)$ does not cause Ang I production even at a concentration 10,000 times higher than normal physiological levels of mouse renin (Fig. 5), although both human and mouse renin equally activates ERK1/2 in mouse vascular smooth muscle cells. Thus, the obesity phenotype observed in human renin transgenic mice underscores the importance of an Ang-independent role of renin in regulating body weight possibly via (pro)renin receptor.

\section{Human Renin Transgenic Rats}

Human renin transgenic rats developed moderate obesity mainly due to increased food intake [40]. However, when they were calorie restricted and pair-fed, $\mathrm{h} R E N T g$ rats became even leaner than non-transgenic control rats because they have increased energy expenditure, exercise, thermogenesis and lipid oxidation. Because this transgene is highly expressed in the hypothalamus, the metabolic phenotype of $\mathrm{h} R E N T g$ rats might not reflect Ang II-independent effects of endogenous renin.

\section{Mouse Renin Transgenic Mice}

Caron and Smithies generated three lines of unique mouse renin transgenic mice using the albumin promoter/enhancer, and targeting the transgene into the ApoA1C3 locus [41-43]. The transgenes have a furin cleavage site and the active renin is generated and secreted from the liver without feedback regulation. The three mouse lines have different levels of renin, BP, and cardiac and renal fibrosis.
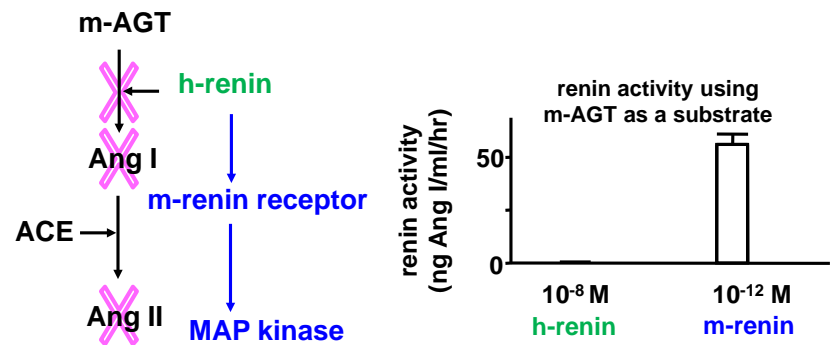

Fig. (5). Human (h-) renin does not generate Ang I from mouse (m-) AGT. Human renin does not generate Ang I from mouse AGT.

\section{Prorenin and Renin Receptor}

The (pro)renin receptor (PRR) is a single transmembrane protein of 350 amino acids. This specific renin receptor, discovered by Nguyen and colleagues in 2002, has dual functions (Fig. 6): (i) increases catalytic activity of the PRRbound prorenin to produce Ang I [44] (Fig. 1); and (ii) activates MAP kinases independently of Ang II [45]. When prorenin binds PRR, a conformational change occurs in the prorenin molecule conferring full enzymatic activity and the ability to produce Ang I without undergoing proteolytic cleavage [reviewed in [46]]. Prorenin makes up 70-90\% of total circulating renin [47], but it will not be converted to renin [48], which is synthesized only in the kidney. The binding of prorenin and renin to the cell surface in tissues is of pivotal importance in the physiology of local RAS in organs, since it provides a mechanism to generate Ang II locally in excess of the Ang II that is produced in plasma. Nguyen and colleagues also demonstrated that the binding of renin to its receptor increases the conversion rate of AGT to Ang I by four-fold [45]. In addition, both renin and prorenin bind to the PRR with similar affinity and activate the MAP kinase pathway $[45,47,49]$.

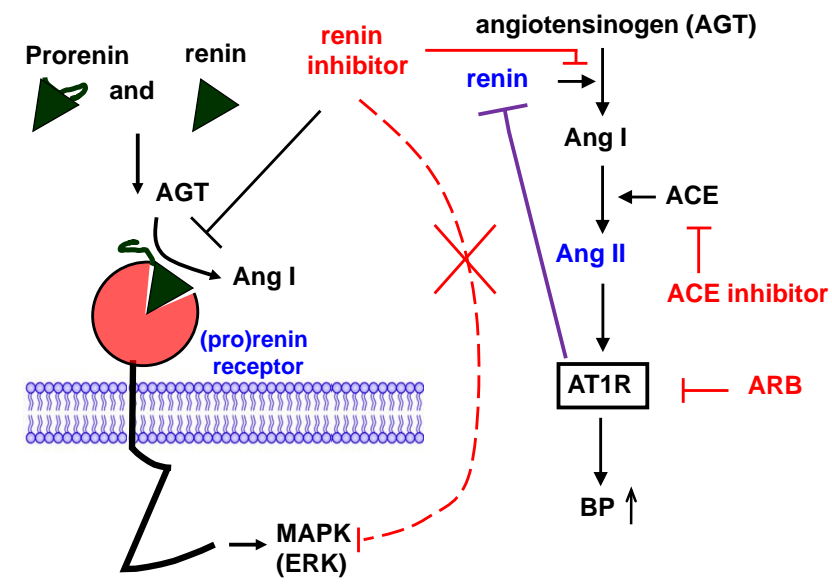

Fig. (6). Classical RAS pathway and novel effects of (pro)renin mediated by (pro)renin receptor. Prorenin and renin effects via PRR include Ang II-dependent and independent actions. Ang IIdependent actions involve increased catalytic activity of the PRRbound prorenin to generate Ang I from AGT. Ang II-independent action involves intracellular signaling that triggers activation of an extracellular signal-related protein kinase (ERK1/2) pathway.

Abnormal signaling from the (pro)renin receptor is involved in cardiac fibrosis [50], nephrosclerosis [51], and microvascular complications [52]. Binding of PRR to its receptor in renal glomerular mesangial cells and cardiomyo- 
cytes activates ERK and p38, respectively, independent of Ang II [45, 53]. The (pro)renin receptor is highly conserved in human, mouse, rat, and other species [47], and our preliminary data show that human renin and mouse renin are equally effective at activating MAPK in mouse cells.

A silent transition at $321 \mathrm{C}>\mathrm{T}$ in exon 4 of PRR causes inefficient inclusion of exon 4 and impairment of ERK1/2 activation, which presents in patients with X-linked mental retardation [54]. In addition, $T$ allele carriers of the PRR gene intervening sequence polymorphism in intron 5 [(IVS) $5+169 \mathrm{C}>\mathrm{T}]$ have higher BP in Japanese men than C allele carriers [55].

A renin inhibitor, aliskiren, inhibits Ang I synthesis and is widely used for treatment of hypertension [56]. Ichihara and colleagues proposed using a 10-amino acid sequence of the prorenin prosegment, termed "handle region peptide (HRP)", and demonstrated that HRP blocks binding of prorenin to PRR [52]. These authors showed that subcutaneous administration of HRP to streptozotocin-induced diabetic rats decreased renal content of Ang I and Ang II, and inhibition of diabetic nephropathy [52]. However, Feldt et al. were not able to block prorenin and renin-induced ERK1/2 activation by HRP or aliskiren [49]. It is possible that HRP efficacy in vivo depends on an undefined mechanism rather than competitive antagonism for the PRR.

The properties and binding specificities of the PRR, and its function in disease states such as the metabolic syndrome, remain a matter of debate.

\section{Angiotensin Converting Enzyme (ACE)}

ACE, mainly expressed in endothelial cells, removes two C-terminal amino acids from Ang I to generate Ang II [57]. ACE inhibitors are widely used and potent anti-hypertensive drugs. ACE I/D polymorphism in intron 16 is associated with altered plasma ACE levels, ranging from $75 \%$ in I/I, to $100 \%$ in I/D (by definition) and $125 \%$ in $\mathrm{D} / \mathrm{D}$ individuals [58]. Yet, unlike the $A G T$ polymorphism, the $A C E \mathrm{I} / \mathrm{D}$ polymorphism does not significantly affect BP [59]. Mice lacking ACE have a striking reduction in $\mathrm{BP}$, inability to concentrate urine, anemia, and a marked reduction in male fertility [60, 61]. Renal papilla is markedly reduced in these mice, and the intrarenal arteries exhibit vascular hyperplasia associated with a perivascular inflammatory infiltrate $[12,60]$. The tailcuff BP of the Ace-/- mice is $\sim 73 \mathrm{mmHg}$, over $30 \mathrm{mmHg}$ less than what is seen in wild-type mice [61]. This observation is similar to the phenotype of the Agt-/- mice [22-24], Renlc-/mice [27], and the Agtrla-/-; Agtrlb-/- double-null mice [62, 63], suggesting that the reduction of BP observed in Aceknockout mice is due to the lack of Ang II production.

Heterozygous disruption of Ace, which brought ACE levels to $50 \%$ of wild-type, did not affect BP [64], unlike what is seen in response to mild genetic alteration of $A g t$ expression [65]. Similarly, when the Ace gene was duplicated, BP levels of three-copy heterozygotes and four-copy homozygotes were normal despite their increased plasma ACE (1.5 times and 2 times wild-type levels, respectively) [64]. This is consistent with the finding that humans with the ACE D/D genotype have elevated serum and tissue ACE, but no significant increases in plasma Ang II and BP. However, these individuals have a reduction in the vasodilator bradykinin [66]. This reduction in bradykinin could explain why individuals that are homozygous for the $\mathrm{D}$ allele have a poor prognosis for several cardiac and renal conditions, whereas the I allele is associated with enhanced endurance performance in elite distance runners, rowers, and mountaineers [67-69]. Developing computer simulation was very useful to understand the apparent paradox between the effects of genetic and drug-induced changes in ACE activity [11]. The simulation shows that Ang I (substrate of ACE) decreases with mild increase in ACE, and the effects of the increase in ACE activity are offset, and Ang II (product of ACE) and BP stay at the same levels, but bradykinin (substrate of ACE) decreases. If ACE mildly decreases, the level of Ang I increases and that of bradykinin increases [66]. However, the plasma Ang I cannot increase indefinitely; it eventually plateaus with more substantial inhibition of ACE with ACE inhibitors. Once Ang I has plateaued, further inhibition of ACE decreases Ang II and therefore BP. There are reports demonstrating the association of ACE D/D genotype and the metabolic syndrome $[70,71]$, but the absence of association is also reported as expected in human studies [72, 73].

Mice with 3 copies of Ace that were made diabetic by streptozotocin developed more severe diabetic nephropathy relative to wild type diabetic mice [74]. The ACE D/D genotype is associated with impaired insulin sensitivity and glucose tolerance, obesity $[75,76]$, and increased susceptibility to type 2 diabetes mellitus [77]. ACE D/D genotype is also associated with development of diabetic nephropathy [7882], most likely due to decreased bradykinin. Indeed we have shown that lack of type 2 bradykinin receptor (B2R) exacerbates diabetic nephropathy [83]. The D allele of the ACE gene also may be a risk factor for the development of wall thickening of the carotid artery in NIDDM patients [84]. These observations suggest that ACE inhibition is beneficial for the treatment of diabetes and obesity. Mice lacking ACE have lower body weight and reduced fat mass with improved glucose clearance [37]. Although their food intake and fecal fat excretion are indistinguishable from those of wild-type mice, the Ace-/- mice have higher energy expenditure due to increased metabolism of fatty acids in the liver [37]. Pharmacological inhibition of ACE does not have the same effect on body composition, however $[85,86]$. Reports are inconsistent with regard to the effect of pharmacological inhibition of ACE on body weight $[87,88]$. Heimann et al. found that mice with 3 copies of Ace that were fed a high-fat diet had lower body weight than 1- and 2-copy mice [89]. In addition, these 3-copy mice have lower blood glucose and insulin levels, suggesting improved insulin sensitivity compared with mice that have 1 or 2 copies of the Ace gene [89]. Further investigation is needed into the effects of mild changes in ACE expression on obesity and diabetes.

\section{Bradykinin and its Receptors}

In addition to converting Ang I to Ang II, ACE (also known as kininase II) converts the active vasodilator kinins bradykinin (1-9) and kallidin (1-10) into inactive peptides bradykinin (1-7) and kallidin (1-8), respectively [see review [90] for detail]. The $K_{\mathrm{m}}$ and $k_{\text {cat }} / K_{\mathrm{m}}$ between ACE and the kinins are 30 times lower and 10 times higher, respectively, than between ACE and Ang I, indicating ACE has higher affinity and efficiency for kinins than for Ang I [91]. Modest quantitative changes in ACE expression do not significantly affect BP in humans or mice [59, 64]. Nevertheless, the D 
allele, which causes higher levels of ACE, confers increased risk of a wide constellation of diseases, including diabetic nephropathy, congestive heart failure, and Alzheimer's disease [92-94], possibly due to decreased kinin levels. The kinins, bradykinin and kallidin in humans and rodents, are generated from kininogens by kallikreins. Humans have one kininogen gene while rodents have two closely linked kininogen genes [95, 96]. Kallidin can be converted into bradykinin by a plasma aminopeptidase.

Two receptors for kinins have been identified: B1R and $\mathrm{B} 2 \mathrm{R}$. Both of these receptors are $\mathrm{G}$ protein-coupled receptors with seven transmembrane domains [97]. B2R is constitutively expressed, whereas $\mathrm{B} 1 \mathrm{R}$ is inducible by inflammation and by inhibition of B2R [98]. All the kinins are strong agonists of B2R, with less affinity for B1R [96]. Mice lacking B2R are normotensive, but have increased BP in response to a high-salt diet [99]. The B1R-/- mice have reduced BP [100], and antisense oligodeoxynucleotides targeted to the B1 receptor $\mathrm{mRNA}$ decreased BP in spontaneously hypertensive rats (SHR) [101]. In contrast, a B1R antagonist increased BP in the B2R-/- mice (but not in wildtype mice), suggesting that in the absence of the $B 2 R$ the vascular B1R adopts B2K-like hemodynamic function [99]. In the presence of $B 2 R$, inhibition or removal of $B 1 R$ upregulated B2R [102] and the protective BP lowering phenotype is likely due to augmented B2R effects.

Bradykinin through its receptors sequentially activates PI3-kinase, phosphorylates Akt and endothelial nitric oxide synthase (eNOS). B2R forms a complex with eNOS, from which the active enzyme is released following receptor activation [103]. Bradykinin also increases the association of heat-shock protein 90 with eNOS, which is required for nitric oxide (NO) formation [104]. eNOS is involved in the insulin signaling pathway. Because lack or decrease in eNOS expression leads to the metabolic syndrome [105, 106], it is likely that decreased expression of bradykinin receptors would also lead to the metabolic syndrome. Bradykinin receptors have three $\mathrm{B} 2 \mathrm{R}$ polymorphisms (the $\mathrm{C} / \mathrm{T}-58$ promoter polymorphism, and the exon $2(\mathrm{C} / \mathrm{T} 181)$ and exon 1 (+/-9bp) polymorphisms) and one B1R promoter polymorphism (G/C-699) [107-109]. The B2R exon 1 (-9bp) polymorphism is a susceptibility marker for diabetic nephropathy [107].

The B1R-/- mice are lean and resistant against high-fat diet-induced weight gain, and have increased leptin sensitivity demonstrated by a reduction in food intake and body weight after leptin administration [110]. Thus, selective antagonism of the inducible B1R subtype may constitute a novel therapeutic approach for the treatment of obesity and diabetes [111]. The B2R-/-mice, or blockage of B2R by HOE140 in mice have shown to reduce clearance of glucose [112]. As in the case of BP phenotype, in the presence of $\mathrm{B} 2 \mathrm{R}$, inhibition or removal of B1R upregulates B2R expression [113] and the lean phenotype of B1R-/- mice is likely due to augmented B2R effects. In contrast, in the absence of $\mathrm{B} 2 \mathrm{R}, \mathrm{B} 1 \mathrm{R}$ is upregulated [83], but it is thought that the effect on metabolic function is not strong enough to compensate for the absence of B2R. This hypothesis is being tested by investigating whether inhibition of either one or both of the bradykinin receptors (genetically and pharmacologically) confers obesity and insulin resistance. Blocking B1R, or in- creasing B2R activity, may provide a therapeutic strategy for the metabolic syndrome.

\section{Angiotensin-Converting Enzyme 2}

ACE2, discovered in 2000, is a homologue of ACE and a key player in the conversion of Ang II to Ang(1-7) and Ang I to $\mathrm{Ang}(1-9)$ (Fig. 7). In contrast with ACE, ACE2 does not convert Ang I to Ang II and is not inhibited by ACE inhibitors [114]. ACE2 increases degradation of Ang II and reduces Ang II formation by competitively stimulating alternative pathways for Ang I degradation [114]. ACE2 is expressed on the surface of certain endothelial cell populations. Compared with ACE, the expression pattern of ACE2 is more limited, with highest expression in the kidney, followed by the heart and the testis. Several groups have created mice lacking ACE2. Crackower et al. reported that Ace 2 gene ablation severely impairs cardiac contractility and causes mild ventricular dilation and increased Ang II levels, but not alterations in BP [115]. Ablation of both Ace and Ace 2 prevented these cardiac abnormalities and the increase in Ang II formation. Thus, ACE and ACE2 probably counteract each other in terms of enzymatic activity and function [115]. In contrast, Gurley \& Coffman demonstrated enhanced susceptibility of the Ace2-/- mice to Ang II-induced hypertension without detectable alteration in cardiac structure and function [116]. Yamamoto and colleagues reported normal baseline cardiac function in their Ace2-/- mouse, but found an accelerated cardiac dysfunction after aortic banding associated with enhanced accumulation of Ang II in the heart [117]. More detailed similarities and differences in these studies are reviewed in [118].

Mice lacking the Mas receptor have increased BP and exhibit increased anxiety, while ACE2 transgenic rats have low BP and cardioprotective effects [119]. In primary cultures of human cardiomyocytes, Ang(1-7) and Ang II have opposite and antagonistic effects on transcriptional regulation of matrix metalloproteinases (MMPs) and tissue inhibitors of metalloproteinases (TIMPs) [120]. This suggests a potential role for $\mathrm{Ang}(1-7)$ in attenuating cardiac damage in Ang II-induced extracellular matrix remodeling. The mechanism of the antiproliferative effect of Ang(1-7) in

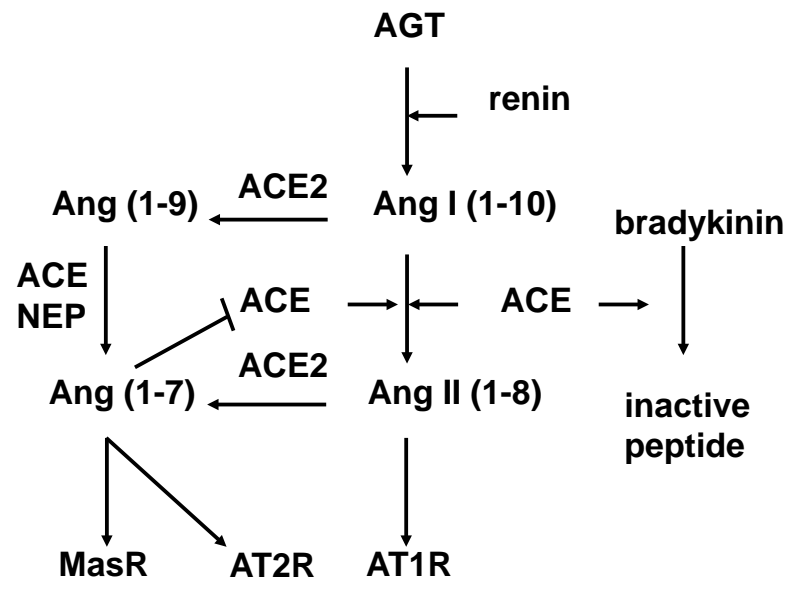

Fig. (7). Role of ACE2 in the RAS. ACE2 is a key player in the conversion of Ang II to $\operatorname{Ang}(1-7)$ and Ang I to $A n g(1-9)$, and counteract the effects of Ang II. Different from ACE ACE2 does not convert Ang I to Ang II, or regulate plasma bradykinin levels. 
the heart could be mediated by inhibition of Ang II-induced extracellular signal-regulated kinase 1 and 2 (ERK1/2) signaling [121]. ACE2 levels in the cardiovascular system are critical for the vasodilatory, antiproliferative effects of the ACE2-Ang(1-7)-MasR pathway.

Male Ace 2 KO mice displayed a selective decrease in first-phase insulin secretion in response to glucose and a progressive impairment of glucose tolerance compared with wild-type mice [122]. Mice lacking ACE2 also exhibit accelerated diabetic nephropathy with increased urinary albumin excretion, mesangial matrix scores, and glomerular basement membrane thicknesses [123].

\section{Chymase}

ACE is generally considered to be the main Ang IIproducing enzyme in the systemic circulation. In tissues, however, many serine proteases, such as cathepsin $G$ and chymases, appear to be capable of producing Ang II. Chymases are primarily in mast cells [124], but are also found in endothelial and mesenchymal cells [125], and in the human heart as a mechanism of ACE-independent Ang II production [126]. ACE inhibition does not block chymase generation of Ang II. Studies using a chymase inhibitor, and transgenic mice overexpressing human chymase, indicate that chymase causes hypercholesterolemia and atherosclerosis [127, 128]. Increased chymase activity is strongly associated with various cardiac diseases, such as myocardial ischemia, volume overload cardiac failure, cardiomyopathy, and viral myocarditis, suggesting that increased cardiac chymase activity is involved in cardiac remodeling. Chymase plays an important role in diabetes; the protein is markedly upregulated in the diabetic kidney and may be associated with the development of diabetic nephropathy [129]. The chymase inhibitor TY-51469 protects against pancreatic islet disorganization caused by streptozotocin [130]. Blocking alternative Ang II-producing pathways, such as chymases, may be beneficial in treating diabetes.

\section{Ang II Receptors}

Ang II has two receptors, the Ang II type I receptor (AT1R) and the Ang II type II receptor (AT2R). Both receptors are G-protein-coupled receptors with seven transmem- brane domains [131]. The AT1R and AT2R subtypes have similar Ang II-binding properties but different genomic structure and localization, as well as tissue-specific expression and regulation. The AT1R is responsible for the classical actions of Ang II such as vasoconstriction, aldosterone release from the adrenal zona glomerulosa, salt retention in the renal tubules, and stimulation of the sympathetic nervous system. AT2R plays an important role in the growth, differentiation, and regeneration of neuronal tissue [132, 133].

The A1166C polymorphism in the 3'UTR of AT1R is strongly associated with the incidence of essential hypertension and increased coronary artery vasoconstriction [134], cardiac hypertrophy [135], and diabetic nephropathy [136], and predicts the development of the metabolic syndrome[137, 138]. Humans have only one AT1R, but mice have two AT1R subtypes: AT1aR and AT1bR (Agtrla and Agtrlb) [139]. Their signaling mechanisms are almost identical but the regulation of their expression differs. AT1aR is dominant in most tissues relevant to the cardiovascular system, while AT1bR is only expressed in pituitary glands, testes, and adrenal gland [140,141]. The type 2 receptor is highly and widely expressed during fetal development; but in adults, its expression is confined to the adrenal medulla, uterus, ovary, vascular endothelium and certain areas of the brain. AT2R appears to counterbalance some of the effects of AT1R by inducing vasodilatation, growth arrest and apoptosis (Fig. 8).

Deletion of AT1aR causes hypotension and an increase in renin which leads to a profound increase in Ang II. Interestingly, Agtr1b-/- mice exhibit normal BP and pressor response to Ang II [142], whereas mice lacking both AT1aR and AT1bR have low BP similar to Agt-/- mice [143]. The dual null Agtrla-/-; Agtrlb-/- mice also develop abnormal renal phenotypes identical to those observed in the Agt-/-, Ace-/-, and Renlc-/- mice. In contrast, mice lacking the AT2R gene do not exhibit these phenotypes. BP in the Agtr2-/- mice is approximately 3-17 $\mathrm{mmHg}$ higher than in wild-type mice [144].

When the Agtr2-/- mice were treated with deoxycorticosterone acetate (DOCA) and salt, it became obvious that they are salt sensitive [144]. The Agtr2-/- mice show congenital

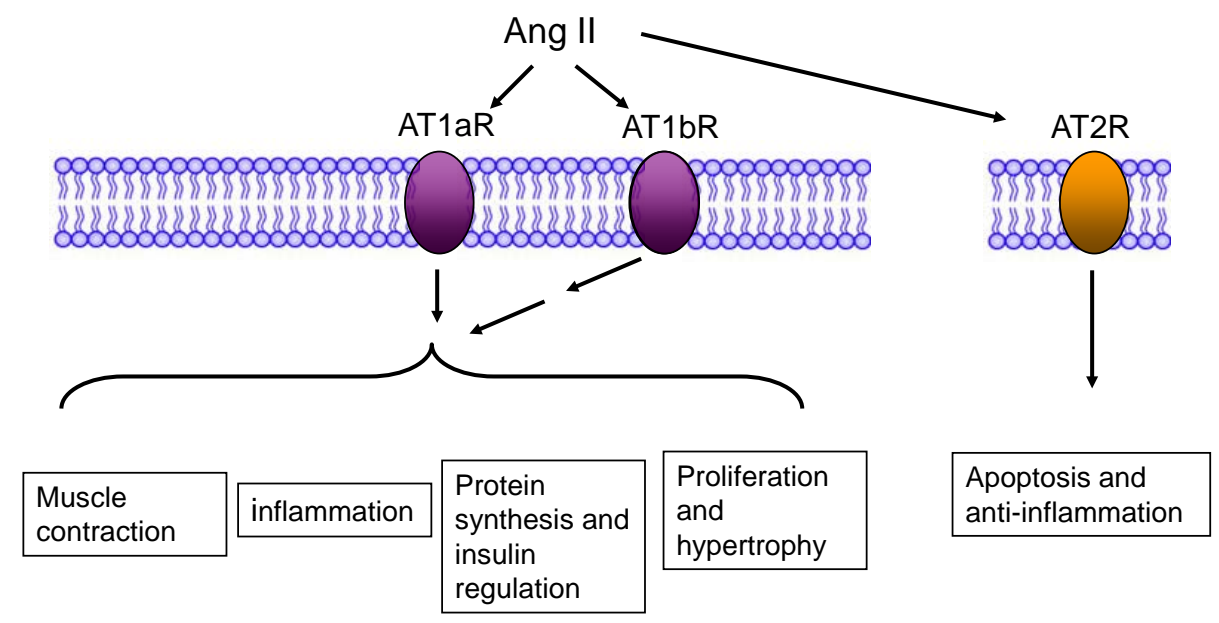

Fig. (8). Ang II receptor. Type 1 Ang II receptor (AT1R, AT1aR and AT1bR in mice) mediates the majority of Ang II effects, and regulates muscle contraction, inflammation, insulin levels and cell proliferation, while AT2R regulates apoptosis. 
anomalies of the kidney and urinary tract (CAKUT) as observed in humans, namely lack of interstitial fibrosis at birth, with some hypoplastic, cystic, and/or dysplastic parenchyma [145]. They also identified a single nucleotide transition (A$1332 \mathrm{G}$ ) in intron 1 of the AGTR2 gene in patients with CAKUT, which decreases the amount of AGTR2 mRNA expression.

Kouyama et al. have shown that the Agtrla-/- mice are lean, resistant to diet-induced obesity, with improved insulin sensitivity [146]. These authors also found that these mutant mice have increased sympathetic activity and energy expenditure, probably due to the activation of AT1bR. These observations suggest that Agtrla-/- mice are protected from some components of the metabolic syndrome. In addition, blocking AT1R with losartan activates the insulin-mediated IRS1/PI3/GLUT4 cascade in skeletal muscle and white adipose tissue, leading to improved glucose tolerance and insulin sensitivity [147]. AT2R is expressed in the heart, kidney, brain, uterus, and adipose tissue [148]. AT2R expression in adipose tissue is low, but AT2R seems to mediate Ang II stimulation of adipose tissue development [149]. AT2R can induce production and release of prostacyclin from adipocytes, which in turn stimulates differentiation of preadipocytes [150]. Mice lacking Agtr2 have increased glucose uptake in adipose tissues [150]. Laurent et al. have shown that the $\operatorname{Agtr} 2^{\mathrm{y} /-}$ mice (AT2R gene is on the $\mathrm{X}$ chromosome) have normal adiposity but display small adipocytes at an increased number [151]. These authors found that mice lacking Agtr2 have increased lipid oxidation, which is caused by increased expression of fatty acid translocase, uncoupling protein-3, peroxisome proliferation activated receptor $(\alpha, \delta)$, and carnitine palmitoyl transferase-1 (CPT-1). In agreement with their lean phenotype, the Agtr $2^{\mathrm{y} /-}$ mice have decreased food intake and increased total energy expenditure. These studies indicate that inhibition of AT1R and AT2R improves insulin sensitivity and causes fat loss, which is in agreement with the involvement of Ang II in the insulin signaling pathway and in the control of adipose tissue metabolism.

\section{Pharmacological Inhibition of RAS}

Blocking RAS with ACE inhibitors or Ang receptor blockers (ARB) has become a crucial element of cardiovascular and renal medicine. Clinical studies indicate that ARBs and ACE inhibitors prevent the onset of diabetes and improve insulin sensitivity $[152,153]$. In mice, blocking AT1R improves insulin sensitivity and other diabetes symptoms due to increased glucose uptake in skeletal muscle and white adipose tissue [154]. This is due to enhanced insulin signaling and GLUT4 translocation to the plasma membrane [154]. Treatment with ARBs (losartan, or candesartan) does not reverse diabetes, but it effectively improves glucose tolerance and protects $\beta$-cell function by attenuating oxidative stress, islet fibrosis, sparse blood supply, and disruption of ultrastructure in a dose-dependent and BP-independent manner [155]. In addition, ARBs may protect the pancreas in type II diabetic animal models with enhanced insulin secretion [156]. Furthermore, in diabetic models, some ARBs induce adipocyte differentiation by increasing peroxisome proliferator-activated receptor-gamma (PPAR $\gamma$ ) in adipose tissue [157]. Accordingly, ARBs could be a novel form of treatment for the metabolic syndrome and associated pathological disorders.
Moreover, aliskiren is a novel renin inhibitor for the treatment of hypertension [158]. This renin inhibitor has protective effects on endothelial function and atherosclerotic changes. Lu et al. showed that aliskiren resulted in striking reductions of atherosclerotic lesion size in both the aortic arch and the root in fat-fed LDL receptor-deficient $\left(\mathrm{Ldlr}^{-{ }^{-}}\right)$ mice [159]. Furthermore, cotreatment with aliskiren and an ARB has additive protective effects [160]. Thus, aliskiren may also be a promising protective drug for patients with hypertension and diabetes [161].

\section{Summary and Future Perspectives}

In the past decade we have seen a dramatic improvement of our understanding of RAS. An overactive RAS has been shown to be associated with the metabolic syndrome using gene targeting approaches in animal models. Clinical trials have shown that ACE inhibitors and ARBs have beneficial effects on insulin sensitivity. However, uncovering the physiological roles of the Ang-independent effects of renin, PRR, and ACE2 will require additional study. The challenge over the next decade will be to gain a better understanding of the physiological and pathophysiological roles of RAS to identify new therapeutics for the metabolic syndrome.

\section{ACKNOWLEDGMENTS}

The authors thank Drs. Guido Geric, Hyung-Suk Kim, Weili Lin, Nobuyo Maeda and Oliver Smithies for their assistance.

This work is supported by grants from the National Institutes of Health (HL 077145, DK076131, HL49277, P30DK56350), American Heart Association (0855335E), and UNC Department of Pathology and Laboratory Medicine.

\section{REFERENCES}

[1] Alberti KG, Eckel RH, Grundy SM, et al. Harmonizing the metabolic syndrome: a joint interim statement of the International Diabetes Federation Task Force on Epidemiology and Prevention; National Heart, Lung, and Blood Institute; American Heart Association; World Heart Federation; International Atherosclerosis Society; and International Association for the Study of Obesity. Circulation 2007; 120: 1640-5.

[2] Ervin RB. Prevalence of metabolic syndrome among adults 20 years of age and over, by sex, age, race and ethnicity, and body mass index: United States, 2003-2006. National health statistics reports; no 13. Hyattsville, MD: National Center for Health Statistics 2009.

[3] Lusis AJ, Attie AD, Reue K. Metabolic syndrome: from epidemiology to systems biology. Nat Rev Genet 2008; 9: 819-30.

[4] Alberti KG, Zimmet P, Shaw J. The metabolic syndrome--a new worldwide definition. Lancet 2005; 366: 1059-62.

[5] Grundy SM, Cleeman JI, Daniels SR, et al. Diagnosis and management of the metabolic syndrome: an American Heart Association/National Heart, Lung, and Blood Institute Scientific Statement. Circulation 2005; 112: 2735-52.

[6] Elfont RM, Epstein AN, Fitzsimons JT. Involvement of the reninangiotensin system in captopril-induced sodium appetite in the rat. J Physiol 1984; 354: 11-27.

[7] Ganong WF. The brain renin-angiotensin system. Annu Rev Physiol 1984; 46: 17-31.

[8] Baltatu O, Bader M. Brain renin-angiotensin system. Lessons from functional genomics. Neuroendocrinology 2003; 78: 253-9.

[9] Paul M, Poyan Mehr A, Kreutz R. Physiology of local reninangiotensin systems. Physiol Rev 2006; 86: 747-803.

[10] Takahashi N, Smithies O. Human genetics, animal models and computer simulations for studying hypertension. Trends Genet 2004; 20: 136-45. 
[11] Takahashi N, Hagaman JR, Kim HS, et al. Minireview: computer simulations of blood pressure regulation by the renin-angiotensin system. Endocrinology 2003; 144: 2184-90.

[12] Esther CR, Jr, Marino EM, Bernstein KE. The role of Angiotensinconverting enzyme in blood pressure control, renal function, and male fertility. Trends Endocrinol Metab 1997; 8: 181-6.

[13] Santos RA, Castro $\mathrm{CH}$, Gava E, et al. Impairment of in vitro and in vivo heart function in angiotensin-(1-7) receptor MAS knockout mice. Hypertension 2006; 47: 996-1002.

[14] Achard V, Boullu-Ciocca S, Desbriere R, et al. Renin receptor expression in human adipose tissue. Am J Physiol Regul Integr Comp Physiol 2007; 292: 274-82.

[15] Nguyen G. The (pro)renin receptor: pathophysiological roles in cardiovascular and renal pathology. Curr Opin Nephrol Hypertens 2007; 16: 129-33.

[16] Clasen R, Schupp M, Foryst-Ludwig A, et al. PPARgammaactivating angiotensin type-1 receptor blockers induce adiponectin. Hypertension 2005; 46: 137-43.

[17] Erbe DV, Gartrell K, Zhang YL, et al. Molecular activation of PPARgamma by angiotensin II type 1-receptor antagonists. Vascul Pharmacol 2006; 45: 154-62.

[18] Jones BH, Standridge MK, Moustaid N. Angiotensin II increases lipogenesis in 3T3-L1 and human adipose cells. Endocrinology 1997; 138: 1512-9.

[19] Brand E, Chatelain N, Paillard F, Tiret L, et al. Detection of putative functional angiotensinogen (AGT) gene variants controlling plasma AGT levels by combined segregation-linkage analysis. Eur J Hum Genet 2002; 10: 715-23.

[20] Inoue I, Nakajima T, Williams CS, et al. A nucleotide substitution in the promoter of human angiotensinogen is associated with essential hypertension and affects basal transcription in vitro. J Clin Invest 1997; 99: 1786-97.

[21] Jain S, Li Y, Patil S, Kumar A. A single-nucleotide polymorphism in human angiotensinogen gene is associated with essential hypertension and affects glucocorticoid induced promoter activity. J Mol Med 2005; 83: 121-31.

[22] Kim HS, Krege JH, Kluckman KD, et al. Genetic control of blood pressure and the angiotensinogen locus. Proc Natl Acad Sci USA 1995; 92: 2735-9.

[23] Okubo S, Niimura F, Matsusaka T, et al. Angiotensinogen gene null-mutant mice lack homeostatic regulation of glomerular filtration and tubular reabsorption. Kidney Int 1998; 53: 617-25.

[24] Tanimoto K, Sugiyama F, Goto Y, et al. Angiotensinogen-deficient mice with hypotension. J Biol Chem 1994; 269: 31334-7.

[25] Lochard N, Silversides DW, van Kats JP, et al. Brain-specific restoration of angiotensin II corrects renal defects seen in angiotensinogen-deficient mice. J Biol Chem 2003; 278: 2184-9.

[26] Massiera F, Seydoux J, Geloen A, et al. Angiotensinogen-deficient mice exhibit impairment of diet-induced weight gain with alteration in adipose tissue development and increased locomotor activity. Endocrinology 2001; 142: 5220-5

[27] Takahashi N, Lopez ML, Cowhig JE Jr, et al. Ren1c homozygous null mice are hypotensive and polyuric, but heterozygotes are indistinguishable from wild-type. J Am Soc Nephrol 2005; 16: 125-32.

[28] Mansego ML, Redon J, Marin R, et al. Renin polymorphisms and haplotypes are associated with blood pressure levels and hypertension risk in postmenopausal women. J Hypertens 2008; 26: 230-7.

[29] Hasimu B, Nakayama T, Mizutani Y, et al. Haplotype analysis of the human renin gene and essential hypertension. Hypertension 2003; $41: 308-12$

[30] Sigmund CD, Gross KW. Structure, expression, and regulation of the murine renin genes. Hypertension 1991; 18: 446-57.

[31] Clark AF, Sharp MG, Morley SD, et al. Renin-1 is essential for normal renal juxtaglomerular cell granulation and macula densa morphology. J Biol Chem 1997; 272: 18185-90.

[32] Sharp MG, Fettes D, Brooker G, et al. Targeted inactivation of the Ren-2 gene in mice. Hypertension 1996; 28: 1126-31.

[33] Pentz ES LM, Kim HS, et al. Ren1d and Ren2 cooperate to preserve homeostasis: evidence from mice expressing GFP in place of Ren1d. Physiol Genomics 2001; 6: 45-55.

[34] Yanai K, Saito T, Kakinuma Y, et al. Renin-dependent cardiovascular functions and renin-independent blood-brain barrier functions revealed by renin-deficient mice. J Biol Chem 2000; 275: 5-8.

[35] Kakinuma Y, Hama H, Sugiyama F, et al. Anti-apoptotic action of angiotensin fragments to neuronal cells from angiotensinogen knock-out mice. Neurosci Lett 1997; 232: 167-70.
[36] Takahashi N, Li F, Hua K, et al. Increased energy expenditure, dietary fat wasting, and resistance to diet-induced obesity in mice lacking renin. Cell Metab 2007; 6: 506-12.

[37] Jayasooriya AP, Mathai ML, Walker LL, et al. Mice lacking angiotensin-converting enzyme have increased energy expenditure, with reduced fat mass and improved glucose clearance. Proc Natl Acad Sci USA 2008; 105: 6531-6.

[38] Uehara S, Tsuchida M, Kanno T, et al. Late-onset obesity in mice transgenic for the human renin gene. Int J Mol Med 2003; 11: 723 7.

[39] Sinn PL, Davis DR, Sigmund CD. Highly regulated cell typerestricted expression of human renin in mice containing 140- or 160-kilobase pair P1 phage artificial chromosome transgenes. J Biol Chem 1999; 274: 35785-93

[40] Gratze P, Boschmann M, Dechend R, et al. Energy metabolism in human renin-gene transgenic rats: does renin contribute to obesity? Hypertension 2009; 53: 516-23.

[41] Caron KM, James LR, Kim HS, Morham SG, Sequeira Lopez ML, Gomez RA, et al. A genetically clamped renin transgene for the induction of hypertension. Proc Natl Acad Sci USA 2002; 99: 824852

[42] Caron KM, James LR, Lee G, et al. Lifelong genetic minipumps. Physiol Genomics 2005; 20: 203-9.

[43] Caron KM, James LR, Kim HS, et al. Cardiac hypertrophy and sudden death in mice with a genetically clamped renin transgene. Proc Natl Acad Sci USA 2004; 101: 3106-11.

[44] Jan Danser AH, Batenburg WW, van Esch JH. Prorenin and the (pro)renin receptor--an update. Nephrol Dial Transplant 2007; 22: 1288-92.

[45] Nguyen G, Delarue F, Burckle C, et al. Pivotal role of the renin/prorenin receptor in angiotensin II production and cellular responses to renin. J Clin Invest 2002; 109: 1417-27.

[46] Danser AH. (Pro)renin receptors: are they biologically relevant? Curr Opin Nephrol Hypertens 2009; 18: 74-8.

[47] Nguyen G. Renin/prorenin receptors. Kidney Int 2006; 69: 1503-6.

[48] Lenz T, Sealey JE, Maack T, et al. Half-life, hemodynamic, renal, and hormonal effects of prorenin in cynomolgus monkeys. Am $\mathbf{J}$ Physiol 1991; 260: 804-10.

[49] Feldt S, Batenburg WW, Mazak I, et al. Prorenin and renin-induced extracellular signal-regulated kinase $1 / 2$ activation in monocytes is not blocked by aliskiren or the handle-region peptide. Hypertension 2008; 5: 682-8

[50] Ichihara A, Kaneshiro Y, Takemitsu T, et al. Nonproteolytic activation of prorenin contributes to development of cardiac fibrosis in genetic hypertension. Hypertension 2006; 45: 894-900.

[51] Ichihara A, Kaneshiro Y, Takemitsu T, et al. Contribution of nonproteolytically activated prorenin in glomeruli to hypertensive renal damage. J Am Soc Nephrol 2006; 17: 2495-503.

[52] Ichihara A, Hayashi M, Kaneshiro Y, et al. Inhibition of diabetic nephropathy by a decoy peptide corresponding to the "handle" region for nonproteolytic activation of prorenin. J Clin Invest 2004; 114: 1128-35.

[53] Saris JJ, Hoen PA, Garrelds IM, et al. Prorenin induces intracellular signaling in cardiomyocytes independently of angiotensin II. Hypertension 2006; 48: 564-71.

[54] Ramser J, Abidi FE, Burckle CA, et al. A unique exonic splice enhancer mutation in a family with X-linked mental retardation and epilepsy points to a novel role of the renin receptor. Hum Mol Genet 2005; 14: 1019-27.

[55] Hirose T, Hashimoto M, Totsune K, et al. Association of (pro)renin receptor gene polymorphism with blood pressure in Japanese men: the Ohasama study. Am J Hypertens 2009; 22: 294-9.

[56] Frampton JE, Curran MP. Aliskiren: a review of its use in the management of hypertension. Drugs 2007; 67: 1767-92.

[57] Koike G, Krieger JE, Jacob HJ, et al. Angiotensin converting enzyme and genetic hypertension: cloning of rat cDNAs and characterization of the enzyme. Biochem Biophys Res Commun 1994; 198: 380-6.

[58] Rigat B, Hubert C, Alhenc-Gelas F, et al. An insertion/deletion polymorphism in the angiotensin I-converting enzyme gene accounting for half the variance of serum enzyme levels. J Clin Invest 1990; 86: 1343-6.

[59] Lachurie ML, Azizi M, Guyene TT, Alhenc-Gelas F, et al. Angiotensin-converting enzyme gene polymorphism has no influence on the circulating renin-angiotensin-aldosterone system or blood pressure in normotensive subjects. Circulation 1995; 91: 2933-42. 
[60] Esther CR, Jr, Howard TE, Marino EM, et al. Mice lacking angiotensin-converting enzyme have low blood pressure, renal pathology, and reduced male fertility. Lab Invest $\mathbf{J}$ Tech Methods Pathol 1996; 74: 953-65.

[61] Krege JH, John SW, Langenbach LL, et al. Male-female differences in fertility and blood pressure in ACE-deficient mice. Nature 1995; 375: 146-8.

[62] Tsuchida S, Matsusaka T, Chen X, et al. Murine double nullizygotes of the angiotensin type $1 \mathrm{~A}$ and $1 \mathrm{~B}$ receptor genes duplicate severe abnormal phenotypes of angiotensinogen nullizygotes. J Clin Invest 1998; 101: 755-60.

[63] Oliverio MI, Kim HS, Ito M, et al. Reduced growth, abnormal kidney structure, and type 2 (AT2) angiotensin receptor-mediated blood pressure regulation in mice lacking both AT1A and AT1B receptors for angiotensin II. Proc Natl Acad Sci USA 1998; 95: 15496-501.

[64] Krege JH, Kim HS, Moyer JS, et al. Angiotensin-converting enzyme gene mutations, blood pressures, and cardiovascular homeostasis. Hypertension 1997; 29: 150-7.

[65] Cole J, Ertoy D, Bernstein KE. Insights derived from ACE knockout mice. J Renin Angiotensin Aldosterone Syst 2000; 1: 137-41.

[66] Brown NJ, Blais C, Jr, Gandhi SK, et al. ACE insertion/deletion genotype affects bradykinin metabolism. J Cardiovasc Pharmacol 1998; 32: 373-7.

[67] Qadar Pasha MA, Khan AP, Kumar R, et al. Angiotensin converting enzyme insertion allele in relation to high altitude adaptation. Ann Hum Genet 2001; 65: 531-6.

[68] Woods DR, Humphries SE, Montgomery HE. The ACE I/D polymorphism and human physical performance. Trends Endocrin Metab 2000; 11: 416-20.

[69] Moran CN, Vassilopoulos C, Tsiokanos A, et al. The associations of ACE polymorphisms with physical, physiological and skill parameters in adolescents. Eur J Hum Genet 2006; 14: 332-9.

[70] Alvarez-Aguilar C, Enriquez-Ramirez ML, Figueroa-Nunez B, et al. Association between angiotensin-1 converting enzyme gene polymorphism and the metabolic syndrome in a Mexican population. Exp Mol Med 2007; 39: 327-34.

[71] Lee YJ, Tsai JC. ACE gene insertion/deletion polymorphism associated with 1998 World Health Organization definition of metabolic syndrome in Chinese type 2 diabetic patients. Diabetes Care 2002; 25: 1002-8.

[72] Sivakova D, Lajdova A, Basistova Z, et al. ACE insertion/deletion polymorphism and its relationships to the components of metabolic syndrome in elderly Slovaks. Anthropol Anz 2009; 67: 1-11.

[73] Costa LA, Canani LH, Maia AL, et al. The ACE insertion/deletion polymorphism is not associated with the metabolic syndrome (WHO Definition) in Brazilian type 2 diabetic patients. Diabetes Care 2002; 25: 2365-6.

[74] Huang W, Gallois Y, Bouby N, et al. Genetically increased angiotensin I-converting enzyme level and renal complications in the diabetic mouse. Proc Natl Acad Sci USA 2001; 98: 13330-4.

[75] Strazzullo P, Iacone R, Iacoviello L, et al. Genetic variation in the renin-angiotensin system and abdominal adiposity in men: the Olivetti Prospective Heart Study. Ann Intern Med 2003; 138: 17-23.

[76] Riera-Fortuny C, Real JT, Chaves FJ, et al. The relation between obesity, abdominal fat deposit and the angiotensin-converting enzyme gene I/D polymorphism and its association with coronary heart disease. Int J Obes (Lond) 2005; 29: 78-84.

[77] Yang M, Qiu CC, Xu Q, et al. Association of angiotensin converting enzyme gene I/D polymorphism with type 2 diabetes mellitus. Biomed Environ Sci 2006; 19: 323-7.

[78] Kunz R, Bork JP, Fritsche L, et al. Association between the angiotensin-converting enzyme-insertion/deletion polymorphism and diabetic nephropathy: a methodologic appraisal and systematic review. J Am Soc Nephrol 1998; 9: 1653-63.

[79] Azar ST, Zalloua PA, Medlej R, et al. The DD genotype of the ACE gene polymorphism is associated with diabetic nephropathy in the type-1 diabetics. Endocrine Res 2001; 27: 99-108.

[80] Ha SK, Park HC, Park HS, et al. ACE gene polymorphism and progression of diabetic nephropathy in Korean type 2 diabetic patients: effect of ACE gene DD on the progression of diabetic nephropathy. Am J Kidney Dis 2003; 41: 943-9.

[81] Vleming LJ, van der Pijl JW, Lemkes HH, et al. The DD genotype of the ACE gene polymorphism is associated with progression of diabetic nephropathy to end stage renal failure in IDDM. Clin Nephrol 1999; 51: 133-40.
[82] Jeffers BW, Estacio RO, Raynolds MV, et al. Angiotensinconverting enzyme gene polymorphism in non-insulin dependent diabetes mellitus and its relationship with diabetic nephropathy. Kidney Int 1997; 52: 473-7.

[83] Kakoki M, Takahashi N, Jennette JC, et al. Diabetic nephropathy is markedly enhanced in mice lacking the bradykinin B2 receptor. Proc Natl Acad Sci USA 2004; 101: 13302-5.

[84] Hosoi M, Nishizawa Y, Kogawa K, et al. Angiotensin-converting enzyme gene polymorphism is associated with carotid arterial wall thickness in non-insulin-dependent diabetic patients. Circulation 1996; 94: 704-7.

[85] Velkoska E, Warner FJ, Cole TJ, et al. Metabolic effects of low dose angiotensin converting enzyme inhibitor in dietary obesity in the rat. Nutr Metab Cardiovasc Dis 2009; 7: 1-5.

[86] Heise T, Heinemann L, Kristahn K, et al. Insulin sensitivity in patients with essential hypertension: no influence of the ACE inhibitor enalapril. Horm Metab Res 1999; 31: 418-23.

[87] Weisinger RS, Stanley TK, Begg DP, et al. Angiotensin converting enzyme inhibition lowers body weight and improves glucose tolerance in $\mathrm{C} 57 \mathrm{BL} / 6 \mathrm{~J}$ mice maintained on a high fat diet. Physiol Behav 2009; 98: 192-7.

[88] Ades PA, Savage PD, Toth MJ, et al. The influence of obesity and consequent insulin resistance on coronary risk factors in medically treated patients with coronary disease. Int J Obes 2008; 32: 967-74.

[89] Heimann AS, Favarato MH, Gozzo FC, et al. ACE gene titration in mice uncovers a new mechanism for ACE on the control of body weight. Physiol Genomics 2005; 20: 173-82.

[90] Kakoki M, Smithies O. The kallikrein-kinin system in health and in diseases of the kidney. Kidney Int 2009; 75: 1019-30.

[91] Jaspard E, Wei L, Alhenc-Gelas F. Differences in the properties and enzymatic specificities of the two active sites of angiotensin Iconverting enzyme (kininase II). Studies with bradykinin and other natural peptides. J Biol Chem 1993; 268: 9496-503.

[92] Tarnow L, Cambien F, Rossing $\mathrm{P}$, et al. Insertion/deletion polymorphism in the angiotensin-I-converting enzyme gene is associated with coronary heart disease in IDDM patients with diabetic nephropathy. Diabetologia 1995; 38: 798-803.

[93] McNamara DM, Holubkov R, Postava LJ, et al. Pharmacogenetic interactions between angiotensin-converting enzyme inhibitor therapy and the angiotensin-converting enzyme deletion polymorphism in patients with congestive heart failure. J Am Coll Cardiol 2004; 44: 2019-26.

[94] Cheng CY, Hong CJ, Liu HC, et al. Study of the association between Alzheimer's disease and angiotensin-converting enzyme gene polymorphism using DNA from lymphocytes. Eur Neurol 2002; 47: 26-9.

[95] Leeb-Lundberg LM, Kang DS, Lamb ME, et al. The human B1 bradykinin receptor exhibits high ligand-independent, constitutive activity. Roles of residues in the fourth intracellular and third transmembrane domains. J Biol Chem 2001; 276: 8785-92.

[96] Lamb ME, Zhang C, Shea T, et al. Human B1 and B2 bradykinin receptors and their agonists target caveolae-related lipid rafts to different degrees in HEK293 cells. Biochemistry 2002; 41: 14340-7.

[97] Petcu M, Dias JP, Ongali B, et al. Role of kinin B1 and B2 receptors in a rat model of neuropathic pain. Int $\mathrm{J}$ Immunopharmacol 2008; 8: 188-96.

[98] Gama Landgraf R, Jancar S, Steil AA, et al. Modulation of allergic and immune complex-induced lung inflammation by bradykinin receptor antagonists. Inflamm Res 2004; 53: 78-83.

[99] Duka I, Kintsurashvili E, Gavras I, et al. Vasoactive potential of the $b(1)$ bradykinin receptor in normotension and hypertension. Circ Res 2001; 88: 275-81.

[100] Emanueli C, Bonaria Salis M, Stacca T, et al. Targeting kinin B(1) receptor for therapeutic neovascularization. Circulation 2002; 105: 360-6.

[101] Emanueli C, Chao J, Regoli D, et al. The bradykinin B1 receptor and the central regulation of blood pressure in spontaneously hypertensive rats. Br J Pharmacol 1999; 126: 1769-76.

[102] Duguay D, Der Sarkissian S, Kouz R, et al. Kinin B2 receptor is not involved in enalapril-induced apoptosis and regression of hypertrophy in spontaneously hypertensive rat aorta: possible role of B1 receptor. Br J Pharmacol 2004; 141: 728-36.

[103] Lauer T, Kleinbongard P, Preik M, et al. Direct biochemical evidence for eNOS stimulation by bradykinin in the human forearm vasculature. Basic Res Cardiol 2003; 98: 84-9. 
[104] Kobayashi N, Honda T, Yoshida K, et al. Critical role of bradykinin-eNOS and oxidative stress-LOX-1 pathway in cardiovascular remodeling under chronic angiotensin-converting enzyme inhibition. Atherosclerosis 2006; 187: 92-100.

[105] Cook S, Hugli O, Egli M, Vollenweider P, et al. Clustering of cardiovascular risk factors mimicking the human metabolic syndrome X in eNOS null mice. Swiss Med Wkly 2003; 133: 360-3.

[106] Huang PL. eNOS, metabolic syndrome and cardiovascular disease. Trends Endocrinol Metab 2009; 20: 295-302.

[107] Maltais I, Bachvarova M, Maheux P, et al. Bradykinin B2 receptor gene polymorphism is associated with altered urinary albumin/creatinine values in diabetic patients. Can J Physiol Pharmacol 2002; 80: 323-7.

[108] Fallo F, Mulatero P, Vettor R, et al. Bradykinin B2 receptor gene C-58T polymorphism and insulin resistance. A study on obese patients. Horm Metab Res 2004; 36: 243-6.

[109] Braun A, Maier E, Kammerer S, Muller B, et al. A novel sequence polymorphism in the promoter region of the human B2-bradykinin receptor gene. Hum Genet 1996; 97: 688-9.

[110] Mori MA, Araujo RC, Reis FC, et al. Kinin B1 receptor deficiency leads to leptin hypersensitivity and resistance to obesity. Diabetes 2008; 57: 1491-500.

[111] Gabra BH, Berthiaume N, Sirois P, et al. The kinin system mediates hyperalgesia through the inducible bradykinin B1 receptor subtype: evidence in various experimental animal models of type 1 and type 2 diabetic neuropathy. Biol Chem 2006; 387: 127-43.

[112] Damas J, Bourdon V, Lefebvre PJ. Insulin sensitivity, clearance and release in kininogen-deficient rats. Exp Physiol 1999; 84: 54957.

[113] Duka A, Kintsurashvili E, Duka I, et al. Angiotensin-converting enzyme inhibition after experimental myocardial infarct: role of the kinin B1 and B2 receptors. Hypertension 2008; 51: 1352-7.

[114] Donoghue M, Hsieh F, Baronas E, et al. A novel angiotensinconverting enzyme-related carboxypeptidase (ACE2) converts angiotensin I to angiotensin 1-9. Cir Res 2000; 87: 1-9.

[115] Crackower MA, Sarao R, Oudit GY, et al. Angiotensin-converting enzyme 2 is an essential regulator of heart function. Nature 2002; 417: 822-8.

[116] Gurley SB, Allred A, Le TH, Griffiths R, et al. Altered blood pressure responses and normal cardiac phenotype in ACE2-null mice. $\mathrm{J}$ Clin Invest 2006; 116: 2218-25.

[117] Yamamoto K, Ohishi M, Katsuya T, et al. Deletion of angiotensinconverting enzyme 2 accelerates pressure overload-induced cardiac dysfunction by increasing local angiotensin II. Hypertension 2006; 47: 718-26.

[118] Gurley SB, Coffman TM. Angiotensin-converting enzyme 2 gene targeting studies in mice: mixed messages. Exp Physiol 2008; 93 : $538-42$.

[119] Alenina N, Xu P, Rentzsch B, et al. Genetically altered animal models for Mas and angiotensin-(1-7). Exp Physiol 2008; 93: 52837.

[120] Pan $\mathrm{CH}$, Wen $\mathrm{CH}$, Lin CS. Interplay of angiotensin II and angiotensin-(1-7) in the regulation of matrix metalloproteinases of human cardiocytes. Exp Physiol 2008; 93: 599-612.

[121] Giani JF, Gironacci MM, Munoz MC, et al. Angiotensin-(1-7) has a dual role on growth-promoting signalling pathways in rat heart in vivo by stimulating STAT3 and STAT5a/b phosphorylation and inhibiting angiotensin II-stimulated ERK1/2 and Rho kinase activity. Exp Physiol 2008; 93: 570-8.

[122] Niu MJ, Yang JK, Lin SS, et al. Loss of angiotensin-converting enzyme 2 leads to impaired glucose homeostasis in mice. Endocrine 2008; 34: 56-61

[123] Wong DW, Oudit GY, Reich H, et al. Loss of angiotensinconverting enzyme-2 (Ace2) accelerates diabetic kidney injury. Am J Pathol 2007; 171: 438-51

[124] Caughey GH. Mast cell tryptases and chymases in inflammation and host defense. Immunol Rev 2007; 217: 141-54.

[125] Uehara Y, Urata H, Sasaguri M, et al. Increased chymase activity in internal thoracic artery of patients with hypercholesterolemia. Hypertension 2000; 35: 55-60.

[126] Shiota N, Jin D, Takai S, et al. Chymase is activated in the hamster heart following ventricular fibrosis during the chronic stage of hypertension. FEBS Lett 1997; 406: 301-4.

[127] Uehara Y, Urata H, Ideishi M, et al. Chymase inhibition suppresses high-cholesterol diet-induced lipid accumulation in the hamster aorta. Cardiovasc Res 2002; 55: 870-6.
[128] Chen LY, Li P, He Q, et al. Transgenic study of the function of chymase in heart remodeling. J Hypertens 2002; 20: 2047-55.

[129] Huang XR, Chen WY, Truong LD, et al. Chymase is upregulated in diabetic nephropathy: implications for an alternative pathway of angiotensin II-mediated diabetic renal and vascular disease. J Am Soc Nephrol 2003; 14: 1738-47.

[130] Takai S, Jin D, Ohzu M, et al. Chymase inhibition provides pancreatic islet protection in hamsters with streptozotocin-induced diabetes. J Pharmacol Sci 2009; 110: 459-65.

[131] Tamura K, Tanaka Y, Tsurumi Y, et al. The role of angiotensin AT1 receptor-associated protein in renin-angiotensin system regulation and function. Curr Hypertens Rep 2007; 9: 121-7.

[132] Haefliger JA, Bergonzelli G, Waeber G, et al. Renin and angiotensin II receptor gene expression in kidneys of renal hypertensive rats. Hypertension 1995; 26: 733-7.

[133] Amiri F, Haddad G, Garcia R. Renal angiotensin II receptor regulation and renin-angiotensin system inhibition in one-kidney, one clip hypertensive rats. J Hypertens 1999; 17: 279-86.

[134] van Geel PP, Pinto YM, Voors AA, et al. Angiotensin II type 1 receptor A1166C gene polymorphism is associated with an increased response to angiotensin II in human arteries. Hypertension 2000; 35: 717-21.

[135] Osterop AP, Kofflard MJ, Sandkuijl LA, et al. AT1 receptor A/C1166 polymorphism contributes to cardiac hypertrophy in subjects with hypertrophic cardiomyopathy. Hypertension 1998; 32: 825-30

[136] Doria A, Onuma T, Warram JH, et al. Synergistic effect of angiotensin II type 1 receptor genotype and poor glycaemic control on risk of nephropathy in IDDM. Diabetologia 1997; 40: 1293-9.

[137] Palatini P, Ceolotto G, Dorigatti F, et al. Angiotensin II type 1 receptor gene polymorphism predicts development of hypertension and metabolic syndrome. Am J Hypertens 2009; 22: 208-14.

[138] Abdollahi MR, Lewis RM, Gaunt TR, et al. Quantitated transcript haplotypes (QTH) of AGTR1, reduced abundance of mRNA haplotypes containing 1166C (rs5186:A>C), and relevance to metabolic syndrome traits. Hum Mutat 2007; 28: 365-73.

[139] Deshayes F, Nahmias C. Angiotensin receptors: a new role in cancer? Trends Endocrinol Metab 2005; 16: 293-9.

[140] Burson JM, Aguilera G, Gross KW, et al. Differential expression of angiotensin receptor 1A and 1B in mouse. Am J physiol 1994; 267 260-7.

[141] Inagami T, Eguchi S, Numaguchi K, et al. Cross-talk between angiotensin II receptors and the tyrosine kinases and phosphatases. J Am Soc Nephrol 1999; 10: 57-61.

[142] Chen X, Li W, Yoshida H, et al. Targeting deletion of angiotensin type 1B receptor gene in the mouse. Am J Physiol 1997; 272: 299304.

[143] Kanaide H, Ichiki T, Nishimura J, et al. Cellular mechanism of vasoconstriction induced by angiotensin II: it remains to be determined. Circ Res 2003; 93: 1015-7.

[144] Gross V, Obst M, Luft FC. Insights into angiotensin II receptor function through AT2 receptor knockout mice. Acta Physiol Scand 2004; 181: 487-94.

[145] Nishimura H, Yerkes E, Hohenfellner K, et al. Role of the angiotensin type 2 receptor gene in congenital anomalies of the kidney and urinary tract, CAKUT, of mice and men. Mol Cell 1999; 3: 110.

[146] Kouyama R, Suganami T, Nishida J, et al. Attenuation of dietinduced weight gain and adiposity through increased energy expenditure in mice lacking angiotensin II type 1a receptor. Endocrinology 2005; 146: 3481-9.

[147] Henriksen EJ. Improvement of insulin sensitivity by antagonism of the renin-angiotensin system. Am J Physiol 2007; 293: 974-80.

[148] Gulati K, Lall SB. Angiotensin II--receptor subtypes characterization and pathophysiological implications. Indian J Exp Biol 1996; 34: 91-7.

[149] Yvan-Charvet L, Massiera F, Lamande N, et al. Deficiency of angiotensin type 2 receptor rescues obesity but not hypertension induced by overexpression of angiotensinogen in adipose tissue. Endocrinology 2009; 150: 1421-8.

[150] Gallinat S, Busche S, Raizada MK, et al. The angiotensin II type 2 receptor: an enigma with multiple variations. Am J Physiol Endocrinol Metab 2000; 278: 357-74.

[151] Yvan-Charvet L, Even P, Lamande N, et al. Prevention of adipose tissue depletion during food deprivation in angiotensin type 2 receptor-deficient mice. Endocrinology 2006; 147: 5078-86. 
[152] Tjia J, Briesacher BA. Prescription drug benefits and use of guideline recommended medications by elderly Medicare beneficiaries with diabetes mellitus. J Am Geriatr Soc 2008; 56: 1879-86.

[153] Seghieri G, Yin W, Boni C, et al. Effect of chronic ACE inhibition on glucose tolerance and insulin sensitivity in hypertensive type 2 diabetic patients. Diabet Med 1992; 9: 732-8.

[154] Shiuchi T, Iwai M, Li HS, et al. Angiotensin II type-1 receptor blocker valsartan enhances insulin sensitivity in skeletal muscles of diabetic mice. Hypertension 2004; 43: 1003-10.

[155] Shao JQ, Iwashita N, Du H, Wang YT, et al. Angiotensin II receptor blocker provides pancreatic beta-cell protection independent of blood pressure lowering in diabetic db/db mice. Acta Pharmacol Sin 2007; 28: 246-57.

[156] Shao J, Iwashita N, Ikeda F, et al. Beneficial effects of candesartan, an angiotensin II type 1 receptor blocker, on beta-cell function and morphology in db/db mice. Biochem Biophys Res Commun 2006; 344: 1224-33.
[157] Sharma AM, Staels B. Review: Peroxisome proliferator-activated receptor gamma and adipose tissue--understanding obesity-related changes in regulation of lipid and glucose metabolism. J Clin Endocrinol Metab 2007; 92: 386-95.

[158] Kushiro T, Itakura H, Abo Y, et al. Aliskiren, a novel oral renin inhibitor, provides dose-dependent efficacy and placebo-like tolerability in Japanese patients with hypertension. Hypertens Res 2006; 29: 997-1005.

[159] Lu H, Rateri DL, Feldman DL, et al. Renin inhibition reduces hypercholesterolemia-induced atherosclerosis in mice. J Clin Invest 2008; 118: 984-93.

[160] Imanishi T, Tsujioka H, Ikejima $\mathrm{H}$, et al. Renin inhibitor aliskiren improves impaired nitric oxide bioavailability and protects against atherosclerotic changes. Hypertension 2008; 52: 563-72.

[161] Sanoski CA. Aliskiren: an oral direct renin inhibitor for the treatment of hypertension. Pharmacotherapy 2009; 29: 193-212.

(C) Wang et al.; Licensee Bentham Open.

This is an open access article licensed under the terms of the Creative Commons Attribution Non-Commercial License (http://creativecommons.org/licenses/by-nc/3.0/) which permits unrestricted, non-commercial use, distribution and reproduction in any medium, provided the work is properly cited. 